\title{
Managing People in the New Economy
}

Mohan Thite, Lecturer, School of Management, Griffith University, Australia.

\begin{abstract}
People management is central to the thinking and practice of management in today's knowledge economy. Accordingly, all the HR practice areas need to revolve around the creation, sharing and utilisation of knowledge, which is central to a sustainable competitive advantage in the 21st century. However, the HR function has been slow to adapt to new realities and still clings to traditional HR concepts and practices. To create "actionable knowledge" in managing people, HR managers need to overhaul their present tools of the trade: HR planning and recruitment based on narrowly defined job analysis that ignore the changing world of work; performance assessment based on skills and seniority rather than competencies and customer satisfaction; training for immediate needs at scheduled intervals rather than life-long learning on the job with the help of mentors; remuneration based on monetary incentives with little emphasis on the larger work environment; and career management that suited organisational culture and convenience more than employee needs and expectations. The focus of the workshop is to strategically link the practice of HRM to knowledge management in a global environment. The workshop begins with an introduction by the co-ordinator during which he will share the result of his recent research culminating in his just released book, "Managing people in the new economy", published by Sage. According to Prof. Dave Ulrich, "As the new economy becomes an accepted reality, insights from this book will form the foundation for managerial norms and expectations". After the introduction, the coordinator will invite the participants to identify key themes for strategically positioning HRM in the new economy. Thereafter, the participants will be divided into groups to separately debate and discuss each key theme and at the end, come together to share their thoughts with other groups. Thus, the workshop would be conducted in an experiential environment with the active involvement of the participants.
\end{abstract}

Keywords: Strategic HRM, HR \& Knowledge Management, HR in the 21 st century

The following is a summary of the key themes of the author's latest book, "Managing People in the New Economy", published by Sage, New Delhi.

The fuzzy nature of people management and its uncertain outcome make it a daunting task for most organisations to tap the tacit knowledge in people and drives them towards focusing on and investing in information technologies to harness explicit knowledge. However, sooner or later, organisations have to accept the challenge because technology, no matter how brilliant it is, can only provide partial protection from hyper competition and that too only for some time before competitors catch up with it. Further, technology does not like ambiguity, uncertainty and paradoxes. It needs a black and white picture. However, today's workplaces are anything other than black and white.

\section{Managing Paradoxes}

Management is essentially a balancing act. Managers are faced with an endless array of conflicting choices in managing people and their work:

- The difficulty in defining and measuring knowledge work and knowledge workers, such as acquiring knowledge as an end in itself or acquiring it for commercial exploitation, and the danger of creating and glorifying a new class of knowledge workers.
- "Paradoxes inherent in multiple Human Resources (HR) roles", i.e., strategic partner vs. employee champion and change agent vs. administrative expert (Ulrich, 1997).

- The difficulty in measuring the effectiveness of $\mathrm{HR}$ in a learning organisation, particularly in areas that are crucial but are very hard to account for, such as the social architecture or the communities of practices, informal learning, and mentoring.

- The conflict between acquiring speed and agility by being lean and mean in a globally competitive and uncertain environment and the necessity of a long-term relationship with knowledge workers to build trust and passion for organisational goals for a common future.

- The tension between autonomy and structure: freedom induces creativity that may evaporate without a structure but a solid structure may become a stumbling block in generating new ideas.

- The need to create an organisational culture with shared beliefs, values and competencies without encouraging a herd mentality and trampling on the uniqueness of individual personality and creativity.

- The need for different teams and projects to be best in whatever they do by being both competitive and collaborative at the same time. 
Organisations that choose team structure but measure and reward individual performance will go nowhere.

- The competing pressure on Multinational Enterprises (MNE) in dealing with International HRM issues: the internal pressure for standardising HRM practices with business strategy and the external pressure to localise HRM practices with the environment.

There is no use in wishing away paradoxes in the new economy. They are here to stay and grow. The challenge is how each organisation finds its own balance in managing conflicting challenges. Successful learning organisations face this challenge by adopting the principles of holographic design, i.e., to build the whole into parts, deploying variety of functions, skills and design, matching internal complexity to that of the environment, defining no more than is absolutely necessary and endlessly scanning and adapting to the environment (Morgan, 1997).

\section{Road Map for Managing People in the New Economy}

With the realisation that "change has changed" and that change is the only constant phenomenon in the $21^{\text {st }}$ century economy, we need to address the following key issues and challenges in managing people in the new economy:

\section{Navigating the Contours of Knowledge Management}

- Create a dedicated cell in the organisation that is well supported and well resourced to advocate and advance the cause of knowledge management initiatives at the macro and micro levels.

- Define and drive knowledge management primarily in terms of people and their social context - their cultural values, attitudes, competencies, commitment and community spirit.

- Enlist the support of employees at all levels as champions of the cause of KM.

- Comprehensively and collaboratively leverage both IT \& HR interventions to tap explicit and tacit knowledge.

- Successfully deal with the dual nature of "knowledge as knowing" and "knowledge as commodity" (Scarbrough, 1999).

\section{Embedding Strategic HR into Managerial Ethos \& Practice}

- Top management should give the HR function appropriate recognition and status in strategic decision-making and implementation.
- Ensure that HR functionaries are competent enough to discharge their varied and often, conflicting roles of becoming a strategic partner, administrative expert, employee champion and change agent (Ulrich, 1997).

- Treat people management as one of the core responsibilities and accountabilities of all the managers in the organisation and incorporate people management competency as a key success factor in their recruitment, performance assessment, training and reward determination.

- Make the managers realise that employee satisfaction leads to customer and shareholder satisfaction and therefore, are held responsible for employee morale.

- One of the key contributions of HR to KM is to nurture and harness the social energy of knowledge workers in the form of communities of practices within and across organisational boundaries.

- HR policies address the unique contribution and needs of different types of workers (such as, core, contract and casual) in active collaboration with external partners.

- Diversity management is one of the key responsibilities of the HR function in the new economy, aimed at tapping the largely hidden potential of older workers, women and migrants.

\section{Building People-Centric Culture}

- The management is committed to building enduring relationship with employees, customers and shareholders based on trust, fairness and ethics.

- The management demonstrates its trustworthiness, fairness and commitment to ethics through

o longer term outlook and philosophy on management in general,

o treating people management as a long-term investment and not as costs to be reduced or assets to be controlled,

o transparent flow of information,

o reasonable parity between executive and non-executive compensation and other employment matters,

o charting a common future with employees through employee involvement, equitable sharing of wealth and instilling a sense of stability in employment and work organisation, and

o managing stakeholder expectations by under-promising and overdelivering. 


\section{Institutionalising Learning to Learn}

- At the heart of a learning organisation lies the constant endeavour to shape and reshape mental models to suit the changing environment.

- There is no standard way to become a learning organisation. Each organisation has to experiment, learn from failures and chart its own path.

- Creative ideas need space to grow, support to flourish and rewards to be reinforced. Cynicism and bureaucracy kill creativity. Creative people need a community where there is an intense passion to achieve a clear, common goal; diversity is valued and celebrated; sharing and mentoring are natural, and experimentation is a way of life.

- The systems thinking approach requires that each part of the organisation should reflect the whole. While engaged in specific activity, each part should not take its eye off the main and common goal. Together, the parts should detect and act on early warning signals (Senge, 1990).

- A learning organisation values productive failure more than unproductive success (Nadler, 1989).

- Learning is mostly informal and on the job. Therefore, more than formal training activities, it thrives in a culture of natural curiosity, sharing and mentoring. It needs to be navigated by committed leaders and nurtured in a conducive organisational environment.

\section{Attracting Talent}

- The competency framework is grounded in the realisation that today's world of work is radically different than that in the industrial economy and so is the profile of workforce needed. The focus is on the behaviours and characteristics that distinguish a superior performer than the rest. The challenge is how to measure desired competencies and attract those who have them.

- Actions speak louder than policy in creating the image of a compelling place to work. A company that genuinely embraces diversity, is socially responsible, provides learning and development opportunities, treats potential employees like customers and drives the recruitment process with seriousness and commitment, races ahead of competitors in attracting talent.

- Selecting the right talent is a painstaking process with uncertain outcome as no standard formula exists. Selection managers need to develop their intuitive skills based on distilled experience.

\section{Retaining Talent}

- The critical success factor in retaining employees is the alignment between organisational and individual goals. 'Help us but help yourself' attitude to career management erodes trust and confidence in employees (Thite, 2001).

- The key expectation of knowledge workers today is to attain "employability" by working on challenging assignments that give them the much sought after skills, knowledge and competencies.

- Holding managers responsible and accountable for employee morale, sculpting the job to suit individual personality, nurturing social communities in the workplace and honouring the psychological contract are some of the ways to retain key people.

\section{Creating a Performance Enhancement System}

- Instead of becoming a catalyst to improve performance, the appraisal system has degenerated into a malignant tumour and is in urgent need of a radical surgery. Selection of wrong measures that ignore situational factors has lead to the job driving the person. Emphasis on evaluation over development has turned it into a fire-fighting exercise stifling creativity and innovation.

- A good system displays a balanced approach that takes into account both input and output and frequently measured by all the key stakeholders; involves employees in its design, execution and review; and trains managers to be effective coaches in giving feedback and providing developmental opportunities.

\section{Creating a Holistic Reward System}

- The New Pay concepts reflect the need for workplace flexibility required in the new economy. From broadening the base pay to linking pay for performance, the focus is on empowerment and gain sharing. In response to the limitation of traditional framework with an administrative focus, the New Pay systems exhibit a strategic focus in that they highlight the person (instead of job), output or behaviours/competencies (instead of time) and are more inclusive, dynamic, and decentralised (Heneman, Ledford, and Gresham, 2000).

- Distributive justice is at the heart of pay satisfaction.

- Pay for performance can succeed only when performance measures are clearly understood, measured and accepted. It also needs to resolve the tension between individual performance and teamwork. 
- Recognition rewards play a key role in boosting the morale and motivation of knowledge workers. Combined with competitive and equitable remuneration, rewards can be a powerful engine of motivation.

\section{Glocalising People Management}

- Management concepts and practices are culture bound. HRM should therefore be grounded in local realities of the environment and organisation.

- Strong organisational culture may lead to some convergence in international HRM practices facilitating transfer of best practices but lack of sensitivity to cross-cultural differences can be counter-productive.

- The ethical standing of an MNE is under more scrutiny in a foreign land and any compromise will have long-lasting impact on its future prospects.

Despite the realisation that people are central to a service driven knowledge economy, many organisations have done little, if at all, to harness their people's potential. As Bartlett and Ghoshal (2002) describe,

“... a decade of organisational delayering, destaffing, restructuring and reengineering has produced employees who are more exhausted than empowered, more cynical than self-renewing. Worse still, in many companies only marginal managerial attention - if that - is focused on the problems of employee capability and motivation. Somewhere between theory and practice, precious human capital is being misused, wasted or lost... Very few top executives have been able to transform themselves from being analytically driven strategy directors to people-oriented strategy framers. Yet for a traditional company to make the transition into the New Economy, that transformation is vital".

The transformation requires that the management pay utmost attention to development of people by moving away from its obsession with capital based criteria, in judging the success of business. The traditional focus on management by strict measurement, particularly the conventional accounting principles that focus on the short-term, can be harmful to the intellectual health of the organisation.

Successful people management requires that the organisation practice a sound management philosophy that respects human dignity and diversity, is committed to the growth of people, believes in the value of people's contribution, involve them in decision making, and shares its wealth equitably and fairly. Only such a philosophy can truly transform the nature and quality of key HR functions, such as recruitment, learning, performance management and development, remuneration and rewards, industrial relations, and career management. Without the strong foundation of people management philosophy that is practiced as a way of life, no HR management concept can ever have an enduring impact on the bottom line.

The strategic focus on people in the knowledge economy dramatically increases the expectations on HR managers. They have long been used to "operationally reactive" role and now find it challenging to shift to "strategically proactive" role of nurturing an intellectually stimulating environment in the workplace (Brockbank, 1999). Today's employment relationship is as much decided by the knowledge workers as by the company's HR policies, if not more. Instead of asking, "tell us, why we should recruit, train or reward you", the HR managers need to answer "how we can offer mutually satisfying employment terms and conditions so that you find it worthwhile to stay and grow with us".

HR managers also need to overhaul the tools of their trade: HR planning and recruitment based on narrowly defined job analysis, description and specifications that ignore the changing world of work; performance assessment based on skills and seniority rather than competencies and customer satisfaction; training for immediate needs at scheduled intervals rather than life-long learning on the job with the help of mentors; remuneration based on monetary incentives with little emphasis on the larger work environment; and career management that suited organisational culture and convenience more than employee needs and expectations.

Thus, as the industrial economy transforms itself into a knowledge economy, the people management function needs a similar transformation to be able to fulfil its critical role in leveraging intellectual capital as a sustainable competitive advantage. The success of this endeavour depends on the commitment of all managers in the company - from the frontline to the top - in forging endurable collaboration with people - within and outside of organisational boundaries.

\section{References}

Bartlett, C. A. \& Ghoshal, S. (2002) Building competitive advantage through people. MIT Sloan Management Review, Vol. 43 No. 2, pp.34-41.

Brockbank, W. (1999) If HR were strategically proactive: Present and future directions in HR's contribution to competitive advantage, Human Resource Management, Vol 38 No 4, pp. 337-352.

Heneman, R. L., Ledford, G. E. \& Gresham, M. T. (2000) The changing nature of work \& its effects on compensation design \& delivery. In Rynes, S. L., Gerhart, B. (Eds.) Compensation in organisations: Current research \& practice. Jossey-Bass: SF 
Morgan, G. (1997) Images of Organisation. Sage: Thousand Oaks, CA

Nadler, D. (1989) Even failures can be productive. New York Times, $23^{\text {rd }}$ April 1989

Scarbrough, H (1999) Knowledge as work: Conflicts in the management of knowledge workers, Technology Analysis and Strategic Management, Vol 11 No 1, pp.5-16

Senge, P. M. (1990) The Fifth Discipline: The Art \& Practice of the Learning Organisation. Random House: London.

Thite, M. (2001) "Help us but help yourself: The paradox of contemporary career management". The Career Development International, Vol 6 No 6, pp.312-317

Ulrich, D. (1997) Human resource champions: The next agendas for adding value and delivering results, Harvard Business School Press, Cambridge, MA

\begin{abstract}
About the Author
Dr Mohan Thite is a faculty member in the School of Management at Griffith University, Brisbane. He holds a $\mathrm{PhD}$ degree from Swinburne University of Technology and is an Associate Fellow of the Australian Human Resources Institute (AHRI). He is a recipient of 1997 International Research Award from the Centre for Creative Leadership (CCL), USA. Dr Thite has over 15 years of rich and varied experience as Human Resources professional, both in industry and academics. He has published in many journals, such as the International Journal of Project management, Leadership and Organisation Development Journal, Career Development International, International Journal of Human Resources Development and Management, and The Learning Organisation. Many of his published papers have won awards for excellence. His research, teaching and consultancy interests include managing people in the knowledge economy, IT project leadership, cross-cultural management and career management
\end{abstract}

